\title{
Corpos significantes na metrópole discursiva: ensaio sobre fetichismo visual e ativismo juvenil ${ }^{1}$
}

/////////////////// Rosamaria Luiza (Rose) de Melo Rocha ${ }^{2}$

1. Este artigo contém resultados parciais do projeto de pesquisa "Consumo e cena midiática: culturas juvenis e políticas de visibilidade no Brasil" (2010-2012), coordenado pela autora no PPGCOM-ESPM. Uma versão deste ensaio, agora revisto e ampliado, foi apresentada, em outubro de 2011, no V Congresso Internacional El Cuerpo Descifrado, sediado pela UAM, na cidade do México.

2. Doutora em ciências da comunicação pela Escola de Comunicações e Artes da Universidade de São Paulo e pós-doutora em ciências sociais pela Pontifícia Universidade Católica de São Paulo. Coordenadora do Programa de Pós-Graduação Stricto Sensu em Comunicação e Práticas de Consumo da ESPM. E-mail: rrocha@espm.br 


\section{Resumo}

Refletindo sobre o lugar das visualidades e dos corpos na configuração das sociedades contemporâneas (midiatizadas, estetizadas e discursivas), o artigo problematiza a natureza do consumo de imagens que nelas se processa. Argumentando que o fetichismo se converteu, ele mesmo, em um fato de imagem e que o corpo é estruturalmente afetado pela ditadura da visibilidade compulsória, busca-se construir ferramentas analíticas adequadas à identificação e à interpretação de estratégias juvenis de visibilidade nas quais padrões estéticos hegemônicos tomam outro significado ou são confrontados.

\section{Palavras-chave}

corpo, visibilidade, fetichismo, consumo de imagens, juventudes

\section{Abstract}

Focusing on the place of images and bodies in the configuration of contemporary societies (mediated, discursive and aesthetical), this article puts in question the nature of the consumption of images that takes place in this society. Arguing that fetishism has become, himself, an image and the fact that the body is structurally affected by the dictatorship of compulsory visibility, we seek to build analytical tools to identify appropriate strategies and interpretations of juvenile visibility in which hegemonic aesthetic standards are refaced.

\section{Keywords}

body, visibility, fetishism, visual consumption, youth 


\section{Corpos e políticas de visibilidade}

Para falar de corpos significantes, corpos afetados e que resistem e "re-significam" a ditadura da visibilidade compulsória, começo demarcando o olhar que dirijo às imagens. E esse é um olhar de encanto e recusa. De dúvida e de apreço. Afinal, elas são aqui apreendidas, de um lado, como fonte de afecção, o que significa dizer que nem sempre serão mensageiras ou portadoras de afetos felizes. De outro, as compreendo como fonte possível de vinculação. É deste lugar que se podem depreender, em meu argumento, suas possibilidades comunicativas. A cada vez mais estreita convivência entre corpos humanos e imagens tatuou definitivamente o corpo urbano, compondo uma economia simbólica intensa, pulsante, desafiadora. Nossos espaços e nossos tempos metropolitanos, atravessados que são pelas mais variadas redes, pelos processos e fluxos midiáticos colocam-me uma questão - política - de significação. Meus problemas de pesquisa, a partir dessa perspectiva, têm sido também eles demarcados pela interpelação imagética: olhar, interpretar, representar... Essa envergadura teórica, que tem por escopo o debate sobre as imagens e sobre a representação, constitui um guia ou um norteador epistemológico em nossa análise, na qual a visibilidade ganha centralidade.

Em nossas sociedades discursivas, midiáticas e imagéticas, a política, ela própria, tornou-se um caso de imagem, nem sempre resultando em processos nos quais se tornam visíveis sujeitos sociais autônomos e ativos. Pensar as políticas de visibilidade e as políticas de subjetividade aparece, assim, como o primeiro norte a 
3. Sobre "imagética do consumo" ver Rocha (2009). orientar a construção das imagens, em uma acepção ampla (visuais, audiovisuais, táteis e sonoras), como um objeto teórico relevante ao campo da comunicação. É nessa perspectiva que me interessa estabelecer os pilares conceituais para a caracterização do consumo (e do consumo de imagens) nestes tempos que, creio, são "póspós-modernos". Para os objetivos deste pequeno ensaio, destaco inicialmente alguns vetores que compõem hoje os hábitos e as lógicas do consumo. Em primeiro lugar, as culturas do consumo são, desde a nascente modernidade, mediadas por processos comunicacionais. Em segundo lugar, desde a pós-modernidade, essa mediação comunicacional é ancorada em imagens, com forte ênfase naquelas que envolvem - seja no plano da sua produção, seja no plano de sua recepção - a presença de mediações tecnológicas e, como destaca Martín-Barbero (2003), os usos sociais e as apropriações simbólicas dessas tecnologias, o que o autor associa ao termo "tecnicidade". Em terceiro lugar, o consumo seria, irremediavelmente, atravessado por processos de midiatização do social. Em quarto lugar, a imagética do consumo 3 efetiva-se como espaço nuclear de produção, circulação e promoção das narrativas do capital e de interseção entre essas narrativas e diferentes imaginários sociais. Essas e outras convicções levam-me, aqui, a propor um olhar atento às imagens e aos regimes de vinculação com elas estabelecidos, regimes esses que se constituem pela via de uma prole potente e numerosa.

Não será mera casualidade compartilhar, no desenvolvimento de meu raciocínio, das provocadoras hipóteses de Massimo Canevacci (2008), especialmente nos debates que propõe acerca dos fetichismos visuais. Todavia, antes de chegar a essa discussão específica, recorro a dois autores, ambos fundamentais às teorias da imagem em contextos: Baruch de Spinoza e Jesús Martín-Barbero. Seguindo a inspiração do filósofo holandês Benedictus (ou Baruch) de Spinoza, tenho defendido (ROCHA, 2010) que a discussão sobre políticas de visibilidade poderia ser consubstanciada a partir da concepção spinoziana de "afecção". Em um de seus mais notáveis postulados, o pensador discorre sobre a origem e natureza dos afetos, propondo que “[o] corpo humano pode ser afetado de muitas maneiras, pelas quais sua potência de agir é aumentada ou 
diminuída, enquanto outras tantas não tornam sua potência de agir nem maior nem menor" (SPINOZA, 2008, p. 163).

Esse pilar das teorias da afecção relaciona-se à dimensão em essência política do que nos é dado a ver - por meio da profusão de imagens visuais - e, o que particularmente interessa ressaltar, leva-nos a questionar aquelas imagens que, ao nos afetarem, efetivamente aumentam ou diminuem nossa competência corpórea e cognitiva de ação. É também nessa direção que indago sobre uma ética possível para o campo das visualidades, posto que, para o mesmo Spinoza, ética está associada àquilo que aumenta nossa potência de agir.

Em direção similar, Martín-Barbero (2002) tem sido um incansável defensor da dimensão estratégica que hoje assume a comunicação - dimensão a partir da qual, nas palavras do "cartógrafo" mestiço, deve-se pensar a sociedade. Compartilhando da proposta, analisamos a cultura e a sociedade a partir da comunicação. É inegável a centralidade dos processos comunicacionais na vida contemporânea, tanto aqueles de caráter massivo quanto aqueles de natureza maciça, embora, de fato, já não se trate, nesse último caso, de uma comunicação de massa. Uma ética da comunicação demanda a inserção crítica, criteriosa e curiosa nas ecologias comunicacionais e midiáticas da atualidade. Minuciosa e "quente" cartografia desses fluxos de sentido em cruzamento, choque e hibridização.

Ou seja, não se trata de uma questão conteudística a ser debatida: na verdade, os modos de dizer (ou de fazer ver) é que realmente deveriam ser implicados na leitura crítica dos recursos midiáticos e digitais de promover a visibilidade (ou invisibilidade) de fenômenos ou processos socioculturais. Alain Mons (1994), pesquisador da conformação contemporânea da economia ficcional, identifica em sua lógica três figuras centrais: imagem, território, comunicação. Mons procura caracterizar o que chama de "o processo metafórico e suas variantes", defendendo que ele nos introduz em uma economia ficcional que se superpõe a uma economia material. Segundo analisa, as duas disposições "formam um entrelaçamento perfeito na complexidade dos intercâmbios" 
4. No sentido de ser dotada e promotora de diferentes afetos. Afetos, nesse caso, são vinculados às teorias de Spinoza (2008) sobre a afecção, mas também são articulados à ideia de serem nossas sociedades palcos da negociação de sentimentos e sensibilidades, que constituem, fortemente, os processos de significação.
(MONS, 1994, p. 10; tradução nossa). Assim, “a característica de nossa época é que o sistema das representações, o modo simbólico se convertem em flutuantes, aleatórios, metafóricos... [...] processo de expressividade social no qual ficção e realidade se confundem inextricavelmente" (MONS, 1994, p. 10-11; tradução nossa).

Há um discurso publicitário sempre ali, costurando simbólica e literalmente as existências, como se, de fato, a ideia de uma automação tivesse se deslocado dos corpos de metal, de madeira, de eletricidade e de ondas magnéticas para o bios humano. E isso talvez possa ser atribuído à centralidade das visualidades na cena social e "afetual" ${ }^{4}$ da atualidade; imagens que, longe de serem ideologizadas, expressam paradigmaticamente a lógica sexualmente fantasmática que ordena o socius, mas, fundamentalmente, que rege, como sub-reptícia palavra de ordem, a dominância de mecanismos imaginários na regulação e na "des-regulação" social.

É nessa direção e como recurso de contaminação por tal realidade e crítica a ela que o antropólogo da comunicação Massimo Canevacci (2008) recorre ao termo "fetiche", e o faz advertindo-nos de que não irá adotá-lo na orientação corrente. Assim, rechaça a adoção irrestrita da ênfase freudiana, que percebe o fetiche como fonte de perversão, e distancia-se da crítica marxista, que irá localizá-lo no plano da alienação. Segundo o autor, tratar-se-ia de retomar "uma frase que Adorno usa para criticar o método de Benjamin e que este último reivindica como ‘o’ método através do qual penetra nos processos de reificação para dissolvê-los" (CANEVACCI, 2008, p. 19).

Construindo um texto que traz por método a visualidade e o arrebatamento, Canevacci nos convida a acompanhá-lo em sua defesa apaixonada e, como ele mesmo diz, estupefata, de uma necessária crítica à reificação visual. E esse será um assunto de fluxos, saliências e reentrâncias, retomando-se em diversos momentos um sufixo caro ao autor, o de scape. Seu “design etnográfico" é também "uma etnografia fetichista”, porosa, que constrói grandes mapas e panoramas, enfeitiçada para melhor revelar os feitiços. Os "fluxos panorâmicos corpóreos" mobilizados pelo autor nos convidam a uma trilha ocular e analítica sui generis, repleta de corpos-imagens, 
imagens-corpos, corpos-objetos e objetos-corpos sempre em trânsito, sempre em transe, sempre em estado de virtual união: como no fluxo amoroso, o desejo é sempre fugidio, mas, igualmente, sempre se faz inscrever em corpos, territórios, objetos.

Iniciativas de transformação urbana capazes de conversão das cidades em verdadeiras locações comunicacionais, em performances e produções visuais que revertem, via processos de "fetichização", as demandas utilitárias mais potentes serão investigadas pelo autor. Se uma esperança existe, sugere Canevacci, ela reside na sedução, nas iniciativas intersticiais de cruzar e juntar improbabilidades - estéticas, anatômicas, eróticas, teóricas. Mutações culturais sincréticas ganham visibilidade, consolidando, no argumento de nosso autor, algumas proposições. Uma delas nos soa emblemática. Segundo o antropólogo, a experiência com os fetiches e a "fetichização" lança-nos um desafio a um só tempo cognitivo e perceptual, impelindo o olho "a refinar-se em eróptica" (CANEVACCI, 2008, p. 263). Esse olhar tátil, erótico, é o recurso encontrado por Canevacci para viver e pensar as imagens. Afinal, fetichismos visuais são apreendidos em uma "metrópole em corpo": “(um) fetichismo expandido, determinado em grande parte pelos fluxos da metrópole, entrelaçados e hibridizados pelos suores dos corpos, pelos líquidos corporais" (CANEVACCI, 2008, p. 17).

Essa proposta de uma análise das imagens fundada na corporalidade do sujeito cognoscente - capaz, ele próprio, de interpretar as imagens a partir de sua materialidade e da provocação sensória que elas causam - corrobora a hipótese segundo a qual é menos relevante perguntarmo-nos sobre a natureza das imagens que nos cercam, do que indagarmos a natureza das relações que, nós, humanos, estabelecemos com elas. Tendo esclarecido esse ponto de vista, posso agora questionar em que medida essa relação pode ser nomeada de política ou, seria melhor dizer, quando ela pode ser percebida como portadora de "politicidade". Movida por essa indagação, oriento a base teórica de minhas investigações empíricas no sentido de problematizar a categoria "consumo de imagens": afinal, consumimos imagens ou somos por elas consumidos? 
Pesquisadores como Norval Baitello (2010) já nos alertaram para o alcance das dinâmicas de devoração pelas imagens - devoração que pode ser pensada tanto como uma deglutição de imaginários quanto, em seu grau máximo, como uma deglutição de corpos. A lógica da devoração, aliás, é utilizada por Baitello, leitor de Flusser, para discutir a dimensão patológica das sociedades do consumo, justamente aquela em que somos consumidos pelo consumo. Nessa dimensão, o consumismo desenfreado (de produtos, imagens, imaginários e corpos) equivale a uma dissolução imprevista do sistema, a um esquecimento de si, como se nossos próprios corpos, na ânsia de responder à lógica de uma máquina voraz, se convertessem em fetiches. Fetiches visuais, se retornarmos a Canevacci. Em um brilhante ensaio sobre a dizimação capitaneada pelos exércitos nazistas, Jean-François Lyotard (1994), filósofo que se notabilizou por escrever, no final da década de 70 , sobre a chamada pós-modernidade, irá, em um de seus mais belos livros, embora não o mais conhecido, propor uma interessante derivação para pensar a relação entre representação e esquecimento.

Segundo Lyotard (1994), ao contrário do que comumente imaginamos, a forma mais efetiva de apagar fatos da memória é representando-os, repetidamente, excessivamente, de todos os ângulos possíveis, em seus mínimos detalhes. O filósofo ancora sua argumentação em um dos mais sangrentos capítulos da história mundial, o genocídio dos judeus pelos comandos nazistas. Para o autor, "(os) SS fizeram tudo que era possível para apagar os vestígios do extermínio" (LYOTARD, 1994, p. 36). Empreendendo uma leitura radical e assumidamente provocadora, Lyotard propõe que as políticas de esquecimento absoluto empreendidas pelos comandos nazistas dependeram da representação para promover o apagamento máximo dos vestígios do massacre.

Com essa afirmação, Lyotard não está, obviamente, referindose à produção de filmes in loco pelos comandos nazistas - a esse respeito, aliás, Hans Magnus Enzensberger (1996) argumenta com ironia que "não havia câmeras de televisão nos campos de concentração" -, embora sejam recorrentes, ainda hoje, na literatura e no cinema, as referências à nauseante produção de 
narrativas literárias, fotográficas e poéticas, divulgadas em círculos restritos, por dirigentes e ex-dirigentes dos citados comandos. A acusação é mais larga, e o diagnóstico sobre seus efeitos, mais perene. O projeto nazista, pode-se depreender dos argumentos do filósofo, sobreviveu no imaginário de um país e do mundo por décadas, e o fez justamente fazendo-se representação, assim como nesses termos sobreviveu a política de esquecimento por ele proposta. Ou seja, é nessa direção que o autor esclarece que, contrariamente ao que atesta o senso comum, os "crimes perfeitos" não são só os que são operados por um apagamento. Existem outros, profundamente cruéis - aqueles que operam pela representação.

Certas coisas, argumenta Lyotard, não poderiam ou não deveriam ser representadas, muito ao contrário. Lyotard não é o único a defender esse argumento: Peter Pelbart (1994) a ele se referiu, quando analisou a relação entre silêncio e brutalidade; Jurandir Freire Costa (1986) dialoga com ideia similar, ao analisar a violência contemporânea e suas patologias do narcisismo e da visão, referindo-se especificamente à neurose traumática; Michel de Certeau (1995) sinaliza preocupações convergentes quando afirma que determinados fenômenos de violência dos quais fomos testemunhas conferem à palavra uma condição derrisória. E por que a defesa lyotardiana do silêncio? E quais as razões de se tornar um crítico tão contumaz das representações a posteriori de Auschwitz? Ora, isso se dá posto que "não se pode esquecer no sentido comum a não ser aquilo que se pôde inscrever, pois então se poderá apagar":

[...] Representar "Auschwitz" em imagens, em palavras, é uma forma de fazê-la esquecer. Não estou pensando só nos filmes ruins e nas séries de grande audiência, nos maus romances ou nos "testemunhos". Penso até mesmo naquilo que pode ou poderia do melhor modo fazer com que não se esquecesse, pela exatidão, pela severidade. Mesmo isso representa o que deve continuar irrepresentável para não ser esquecido como sendo o esquecido mesmo. Shoah, o filme de Claude Lanzmann, representa uma exceção, talvez a única. [...] Representando, inscreve-se na memória, e isto pode ser uma boa guarda contra o esquecimento. É o contrário, julgo eu. [...] Deve-se temer que a representação-palavra (livros, entrevistas) e a representação-coisa (filmes, fotos) 
do extermínio dos judeus, e dos “judeus” pelos nazistas, lancem de novo a coisa contra a qual se obstinem para a órbita do recalque secundário em vez de deixála esquecida fora de todo o estatuto, no "interior". E se torne, na representação, um "recalque" ordinário (LYOTARD, 1994, p. 36-38).

O recente caso de Osama bin Laden é paradigmático de outro pilar dos processos de esquecimento e extermino do "Mal". Nesse episódio, a astúcia é digna do temor que recaía sobre os governantes norte-americanos, reféns de uma situação paradoxal, na qual poderiam ser tanto adorados quanto criticados por protagonizar esse extermínio mediado pelas imagens, agora não pela via da produção patológica de representações, mas, ao contrário, pelo ocultamento ostensivo dos vestígios. Tornar invisível a consumação da morte de Bin Laden - matá-lo sem representar o cadáver - mantém o temor ao inimigo recalcado, sempre e cada vez mais presente. Se os campos de concentração não tinham câmeras filmadoras, a cena da guerra travada contra os terroristas muçulmanos é plena de registros autorizados e não autorizados. É, sem dúvida, uma guerra potente, política e sangrenta, que envolve disputas viscerais pelo domínio da representação. E, em tal contexto, a morte de Bin Laden não deixa vestígios: nem de corpos nem de imagens, mas propaga, ad infinitum, o imaginário do terror. Em um outro polo desse paradoxo, em que a morte dáse, diversamente, por excesso de exposição, a posterior exumação pública do ditador líbio Muammar Gaddafi, midiaticamente executada, foi também emblemática. Morte feita de sangue e de imagens amadoras; representação da humilhação e da derrota de uma era de terror e poder registrada ao vivo; Gaddafi, cadáver representado, acessado, violado, é expressão paradigmática do ato, compulsivo e compulsório, de revisitar uma imagem traumática, na manutenção do trauma e na tentativa de converter em objeto - e dominando-a, assim - a encarnação do terror.

Em outro plano desse cenário - aquele da representação ostensiva e obrigatória de tudo e de todos -, Hans Magnus Enzensberger (1996), pensador alemão central para a análise da mídia e das formas de violência contemporânea, já citado 
aqui, sugeriu em uma entrevista a adoção, em tempos de excesso e de assédio midiático, de uma autoimputada evasão da realidade. Para ele, como modo de nos protegermos dos danos biográficos gerados pela exposição compulsória, o melhor mesmo seria nos valermos do apelo ao direito à invisibilidade e ao desaparecimento. No argumento de Enzensberger, "a gente tem de se [...] defender. Não muita publicidade, não muitos talk shows [...]. Eu me escondo. Quero ter minha paz. Não quero ser transformado nesta imagem artificial, nesse trademark 'Enzensberger'. Isso é muito perigoso” (1996, p. 7).

O antropólogo Marc Augé (1998) olha esse processo com ironia, chamando a atenção para o protagonismo que a mídia assume em nossa (in)capacidade de lembrar, imaginar e sonhar. Seguindo seu raciocínio, a penetração das narrativas midiáticas em nosso cotidiano é tamanha que ela se tornou um potente agenciador de nossos imaginários, tanto os coletivos - dos mitos, ritos e símbolos - quanto os individuais - dos sonhos propriamente ditos. Sobre essa sorte de amnésia coletiva, Augé afirma que o desenvolvimento das tecnologias comunicacionais liberou um processo de ficcionalização da vida, que contribuiu para a perda da memória e do imaginário. Nesse processo, o esmaecimento da nitidez que permitiria discernir o real do ficcional levaria a um processo de mimetização curioso, no qual a nossa própria percepção e nossa capacidade de relatar o mundo vivido seriam nada mais do que uma reprodução introjetada dos discursos midiáticos.

Como ele relata: "Tive a oportunidade [...] de trabalhar com um jovem de uns trinta anos, vivo e simpático, que me fazia toda manhã o comentário da atualidade". Esse comentário reproduzia o que Augé escutara "palavra por palavra, numa determinada rádio minutos antes". E segue: "Por vezes, surpreendia-me imaginando que, um dia, ele contaria seu último sonho e que eu reconheceria nele o meu, porque nós dois o teríamos visto na televisão" (AUGÉ, 1998, p. 123).

Outro pensador francês, Paul Virilio (1998), escreveu há alguns anos que viveríamos à beira de um crash, tão impactante como aquele das bolsas de valores. Todavia, advertia Virilio, 
a quebra, a síncope que nos ameaça, dizia respeito agora ao excesso e à velocidade de circulação de imagens midiatizadas e, principalmente, estava associada à conversão do próprio mundo em fato de imagem. Nosso urbanista menciona a existência de uma verdadeira estética da desaparição, na qual as cidades, por exemplo, são experimentadas como desertos ou corredores, pontilhados com pontos de partida e de chegada. Nelas, somos programados para passar, e não para permanecer. Prisioneiros do instante e da inércia, não seríamos capazes de esquecer e, portanto, menos ainda de lembrar.

Nas interpretações de Virilio, muitas vezes denominado o “teórico da velocidade", o deslocamento compulsório é percebido como agenciador de uma estética da desaparição. Defendendo a existência de um novo estatuto do olhar e também da liberdade, o filósofo propõe, nesse sentido, que o espaço público foi convertido em imagem pública, e estas, em durações públicas. Para esse estudioso, as máquinas de guerra e os meios de comunicação participam historicamente, como protagonistas, de um projeto de desertificação do real, no qual o espaço é progressivamente colonizado pelo tempo.

Em sua análise ácida e pessimista, vivemos a ameaça de uma cegueira coletiva, verdadeiro crash virtual e temível falência do real. A multiplicação dos serviços audiovisuais - ultrapassando a ótica televisual clássica - e a sucessão de flashes de informação atestariam a oferta de uma condição de telepresença no mundo, reiterada pelo caráter panóptico da televigilância doméstica, uma cultura da suspeição, transformando o território em lugar da insegurança e da desconfiança. Democratização do voyerismo à escala planetária, a informação total convive com a industrialização do esquecimento: do mundo, do tempo histórico, de nós mesmos.

Referindo-se a processo similar, Fredric Jameson, autor de um livro seminal sobre a lógica cultural pós-moderna (1996), também defende que a patologia da contemporaneidade é de ordem temporal. Jameson nos fala da experiência da "presentificação", ou seja, de uma vivência totalizante do aqui e do agora, que nos dificultaria a valoração do passado e, igualmente, nos inviabilizaria a projeção 
do futuro. Para Jameson, o enfraquecimento da historicidade e o que considera uma nova falta de profundidade caminham de mãos dadas. Reféns do instante, párias "memoriográficos", seríamos alegres presas do imediatismo, esse estado de atualização constante, no qual a instantaneidade é também lugar de uma duração eterna.

Por outro lado, devemos lembrar que as novas mídias digitais, com sua memória imaterial, são virtualmente mais "eternas" do que a memória material. Também é assim que hoje podemos reconstruir as lembranças e escrever nossas próprias memórias. É possível identificar nesse lugar virtual a possibilidade de virtualmente nos surpreendermos, sendo ali capturados por situações e encontros inesperados, pela mesma poética da lembrança que um dia encantou o escritor Marcel Proust. Talvez, de fato, possamos paradoxalmente durar através do efêmero.

A aventura da hominização ${ }^{5}$, sabemos, nem sempre

5. Termo de clássica utilização na antropologia e nos estudos da complexidade, mas, igualmente, nas teorias da comunicação e da mídia que dialogam com esses campos do conhecimento, é recorrentemente utilizado, em especial por Edgar Morin, para se referir ao processo de formação e de constituição das diferentes espécies de homos, chegando, até neste momento, à nossa própria, do homo sapiens. correspondeu a uma vitória da civilização, menos ainda da civilidade, base essencial de dois processos complementares que compõem a "politicidade". De um lado, a ética, que associamos àquilo que aumenta nossa potência de agir; de outro a estética, que se articula à nossa potência de sentir. Será necessário, proponho, regressar à gênese do humano. Na leitura moriniana (MORIN, 2000), o homem de cérebro grande só se constitui a partir de um processo: a consciência da morte e o desejo brutal de superá-la. E aqui, justamente nesse ponto, inaugurase, a um só tempo, o que temos de mais propriamente humano e, paradoxalmente, o que de mais "para além do humano" igualmente vai nos caracterizar. Superar os limites da natureza, e, até mesmo, ostensivamente enfrentá-los, parece ser uma das características mais decisivas de nossa hominização.

O embate natureza/cultura, que é aqui retomado, com as teses antropológicas vinculadas às teorias da complexidade, é a brecha através da qual o mundo nos aparece como sendo mediado. Nosso modo de habitar e de fazer mundo responde à entrada em moradas simbólicas que utilizamos para negociar com as incertezas: a casa da 
linguagem, o universo imaginário, os sonhos, os ritos, os devaneios. Só podemos ser racionais, insiste Morin, porque somos também capazes de descomedimento, porque somos, define o autor, da espécie sapiens-demens.

A novidade do sapiens é justamente sua capacidade, erigida ao longo de séculos, de decalcar seu cotidiano com todo um grandioso aparato cognitivo, que é imaginário e "imageante" (produtor de imagens endógenas e exógenas). Vivemos, assim, sempre, em planos de dupla vinculação, em cenários existenciais ambivalentes, posto que são irremediavelmente objetivos e subjetivos. Em tal acepção, a originalidade de nossa espécie não está exatamente em nossa incrível propensão à invenção de técnicas e, posteriormente, de tecnológicas. Antes, pondera Morin, a novidade está colocada em nossas sepulturas e nas pinturas mais originais, residindo, enfim, na nossa capacidade de estruturar complexos imaginários de negociação de nossa finitude, levando-nos a um plano de transmortalidade. Não por acaso, as imagens, signos de ausência e de presença, eram, nos primórdios da civilização, consideradas mágicas, temíveis, poderosas. Poucos eram os que podiam ser transformados em "representação", considerada lugar de distinção social ímpar. A história da iconografia religiosa apenas atesta a dimensão política essencial que está imbricada nesse processo.

\section{Corpos e 'politicidades'}

É clara a visada proposta por autores como Morin, notoriamente reconhecido como um pensador da complexidade do humano e como um defensor da humanização do conhecimento. A fratura no edifício da "Razão" antropocêntrica e tecnocêntrica que se objetiva com tais concepções permite um passo decisivo para a compreensão da "politicidade". Afinal, ela é: 1) um fato bioestético; e 2) um recurso pedagógico que, atualmente, se pode auscultar em cenários plásticos, muitas vezes efêmeros, invariavelmente imagéticos, algumas tantas disparados por "gatilhos" digitais.

As "politicidades", dialogando diretamente com a leitura de Mauro Cerbino (2005), referem-se a ações de forte base estética, 
nas quais o corpo é definidor e demarcador de atitudes específicas e autônomas, caracterizando um exercício de subjetividade que é, ao mesmo tempo, uma recusa consciente do assujeitamento. Em tais ações, evidencia-se justamente um "o que fazer" que provém da vida cotidiana, das práticas estratégicas de vinculação e participação. Segundo explica Cerbino, "o corpo é elemento mediador e lugar de enunciação de uma nova politicidade, de um modo de ocupar e dar sentido ao espaço público e de construir uma cidadania cultural mais além da de direito" (CERBINO, 2005; tradução nossa). Resgatamos ainda, complementando esse debate, o que nos fala Pedro Demo quando, retomando teses de Paulo Freire, defende que a "politicidade" refere-se ao plano da habilidade política humana de "saber pensar" e intervir criticamente (DEMO, 2002).

Se comunicar é se colocar em situação de comunidade, se comunidades são feitas de produções e tensões que nos permitem elaborar e partilhar sentidos, talvez ali mesmo, na fluidez, e na intensidade desses fluxos, seja mais uma vez possível recolher decalques imaginários, construindo, em trânsito e em processo, nossos castelos de memória. Interessa-nos, assim, analisar os processos de midiatização socioculturais na perspectiva das migrações, dos fluxos, das esferas públicas de diáspora, como se exemplificará no tópico seguinte deste artigo. O consumo de imagens em contextos de diáspora tem se apresentado como um lugar igualmente estratégico para analisarmos os efeitos da fúria produtivista das (curiosamente chamadas) sociedades da comunicação. A questão que agora se coloca é: qual a qualidade de vinculação que engendramos nestas sociedades comunicacionais? Se não escolhemos o que ver, podemos escolher como olhar.

\section{Corpos juvenis: sobre 'politicidades' e expressividades}

Tenho identificado, no enfrentamento da "fetichização" dos corpos, algumas ações comunicacionais de fronteira protagonizadas por jovens brasileiros. Buscando construir teoricamente a relação juventude-consumo-cultura-política, estudo diferentes militâncias, subjetivações e ativismos tecnologicamente mediados, aí incluindo 
6. Movimento vinculado, em sua origem, a linhagens do anarcopunk e ao hardcore, de forte crítica ao regime capitalista, à escravização de animais, entre outras ideologias, agregando jovens que rechaçam o consumo de drogas lícitas e ilícitas.

7. Os primeiros resultados consolidados dessa pesquisa sobre as "marchas" foram apresentados, em maio de 2012, no XI Congreso Latinoamericano de Investigadores

de La Comunicación/GT 14

- Comunicación y discurso.

Estudamos, ao todo, 14 marchas organizadas no ano de 2011: Marcha das Vadias; Marcha Mundial pela Paz e pela Não Violência; Marcha da Maconha; Marcha Mundial das Mulheres; Marcha contra

a Construção da Usina de Belo

Monte; Marcha Sexta sem Pele; Marcha da Liberdade; Marcha pelo Estado Laico; Marcha Fora Ricardo Teixeira; Marcha contra Homofobia e pela Aprovação do Projeto de Lei

122; Marcha do Skate; Marcha contra a Violência e Extermínio de Jovens; Marcha pela Educação; Marcha dos Bons Drink. desde as atividades de punks, anarquistas e straight edgers ${ }^{6}$ na cena digital brasileira, com a construção de redes alternativas de consumo e produção cultural, até as diferentes "marchas"7 juvenis, que mesclam fluxos urbanos e presença nas redes sociais.

Como parte da orientação reflexiva até agora consolidada, temos que: a) as expressividades juvenis são identificadas em manifestações e em acontecimentos nos quais jovens em particular ou segmentos juvenis como um todo se assumem como autores e atores de fala, de suas próprias falas, sobre si e sobre o mundo, problematizando imaginários sociais e representações hegemônicas sobre a juventude midiaticamente disseminadas; b) as culturas juvenis são abordadas a partir de uma perspectiva que considera sua conformação eminentemente comunicacional; e c) a comunicação é percebida em uma dupla direção: em sua dimensão antropofilosófica, a reconhecemos como lugar primordial de vinculação; e, em uma ênfase de base sociológica, atentamos para o lugar sociocultural que, ao longo dos anos, foi sendo assumido pelas instituições e pelos veículos destinados à produção e à disseminação de representações audiovisuais tecnicamente mediadas. Ou seja, nossa análise considera e forçosamente discrimina as forças de atuação comunicacional institucionais e não institucionais, midiáticas e não midiáticas, embora entendamos que, em alguns casos, as práticas juvenis dialoguem com ambas ou transitem por elas.

Buscando cartografar as diferentes presenças dos corpos juvenis, as imagens produzidas sobre eles e os imaginários a elas relacionados, vimos localizando estratégias de visibilidade e experiências estéticas juvenis que nos colocam em contato com sujeitos de ação e de discurso (REGUILLO, 2000). Nesse ponto de vista, algumas narratividades juvenis viabilizam ao pesquisador a apreensão das marcas de uma subjetividade pulsante. Mauro Cerbino (2005), retomando proposições de Reguillo, permite-nos associar o campo estético àquele das "politicidades", terminologia adotada pelo autor para caracterizar táticas e estratégias juvenis de aproximação e apropriação de uma realidade profundamente midiatizada. Para ele, essas ações juvenis possuem forte base estética, 
nas quais o corpo é definidor e demarcador de atitudes específicas e autônomas, caracterizando um exercício de subjetividade que é, ao mesmo tempo, uma recusa consciente do assujeitamento, conforme citado anteriormente.

Como já dissemos, no universo acadêmico nacional, encontramos o mesmo conceito, particularmente nas proposições de Paulo Freire. O conceito de "politicidade" é aqui pensado a partir da articulação entre conhecimento e emancipação, ou seja, articula-se a processos de consciência social de sujeitos implicados na construção de autonomia e na criação de alternativas próprias de ser e de estar no mundo. Para o pesquisador da Universidade do Minho (Portugal) Carlos Vilar Estevão, poderíamos atualizar a concepção de Freire, adotando, segundo propõe, o conceito de "cosmopoliticidade": "Este cosmopolitismo democrático tem por detrás a ideia de que a pertença a um Estado ou comunidade não condiciona o compromisso com outras associações e outras lealdades a outros ideais que ultrapassam o Estado-nação" (ESTEVÃO, 2009, p. 4).

Tanto as teorias freirianas quanto as proposições de Cerbino servem-nos para reafirmar, por vias dialógicas, a pertinência do conceito de cenas juvenis - particularmente por esse conceito nos permitir associar a experiência estética a exercícios de consciência de si e do mundo, sendo fundamentos possíveis para o exercício de autonomia e para a construção de autoria.

Caminho em direção à conclusão deste ensaio, consolidando alguns pressupostos: a) a comunicação tornou-se, em especial em contextos latino-americanos, o lugar estratégico a partir do qual se pensar a sociedade, demandando a urgente análise da "tessitura comunicacional do social" (MARTÍN-BARBERO, 2002, p. 36); b) essa acepção dialoga, em nossa leitura, com uma abordagem cara aos estudiosos da cultura urbana. Referimo-nos ao conceito de "cena", em especial na revisão proposta por Will Straw (1997); e c) finalmente, temos que a centralidade comunicacional (MartínBarbero) e o conceito de cena cultural (Straw) são utilizados para elaborar o conceito de cenas juvenis. 
Em contextos de audiovisualização do mundo e abstratização do capital, a crítica à reificação - tal como advogada por Canevacci ao abordar os fetichismos visuais - pode fazer ressoar algumas cenas juvenis que constituem lugares de subjetivação, de ação política e de partilha estética, em que outras significações e outras cidades ganham visibilidade. $\mathrm{O}$ conceito proposto nos permite ainda escapar de demarcações do que seriam os jovens que consideram meramente aspectos etários ou biológicos. A juventude pode assim ser concebida como partícipe de uma estética da vida cotidiana (SARLO, 1997) e, igualmente, ser pensada como ferramenta analítica adotada para nomear conformações geracionais que espelham e potencializam práticas socioculturais mais amplas, de bordas expandidas. Ou seja, ela é concebida como elemento decisivo na construção de uma cena cultural marcada pela sinestesia entre aspectos estéticos, políticos e corporais. Adotar esse conceito, o de cenas juvenis, significa ainda perceber como alguns cenários comunicacionais articulados e "povoados" por jovens constituem paradigmas relevantes, alimentando e reiterando - a contrapelo - imaginários sociais hegemônicos, mas, inúmeras outras vezes, produzindo e colocando em circulação representações e narrativas claramente contra-hegemônicas, desbancando estereotipias ou reconfigurando estigmatizações correntes.

Ações culturais e políticas propostas por jovens brasileiros se utilizam dos espaços virtuais como territórios de encontro e de convocatória para intervenções urbanas que têm mobilizado setores e coletivos juvenis, respondendo a um modelo de comunicação que nada tem de linear. Ou seja, a imagem da "bola de bilhar", que até meados da década de 80 era utilizada como paradigma para representar a comunicação de massa, não se aplica às atuações que se valem de redes sociais tecnologicamente mediadas. Como antevisto pelo antropólogo da cultura Edgar Morin no ano de 1975, a hegemonia da cultura de massas entra em crise, renascendo das suas brechas um novo modo de comunicar: policêntrico, plurivocal, complexo. Mas não necessariamente mais humanista ou humanitário. 
Trata-se de uma ética da comunicação que demanda, como já dissemos, a inserção crítica, criteriosa e curiosa nas ecologias comunicacionais e midiáticas da atualidade. Convido os leitores a me seguir, em próximos artigos, por fluxos de sentido - e de sem sentido - tecidos por algumas narratividades juvenis capazes, segundo proponho, de mover visualidades e, em alguns casos, "fazer visibilidade", ou seja, ganhar lugar de destaque nas agendas política e cultural de nossas sociedades. Essa fusão do midiático ao social também se constitui em bordas e brechas de significação. Diferentes mídias - o corpo, a cidade, os espaços virtuais - são efetivamente suportes através dos quais circulam linguagens e se produzem sentidos disruptivos. 


\section{Referências}

AUGÉ, M. A guerra dos sonhos. Campinas: Papirus, 1998.

BAITELLO, N. A serpente, a maçã e o holograma. São Paulo: Paulus, 2010.

CANEVACCI, M. Fetichismos visuais. São Paulo: Ateliê Editorial, 2008.

CERBINO, M. "Movimientos y máquinas de guerra juveniles". Nómadas, Bogotá, n. 23, p. 112-121, oct. 2005.

CERTEAU, M. A cultura no plural. Campinas: Papirus, 1995.

COSTA, J. F. Violência e psicanálise. Rio de Janeiro: Graal, 1986.

DEMO, P. Politicidade: razão humana. Campinas: Papirus, 2002.

ENZENSBERGER, H. M. "Entrevista”. Fórum Deutsch: revista brasileira de estudos germânicos, n. 1, p. 7-22, 1996.

ESTEVÃO, C. V. "Educação, globalizações e cosmopolitismos: novos direitos, novas desigualdades". Revista Portuguesa de Educação, v. 22, n. 2, p. 35-52, 2009.

FREIRE, P. Educação e mudança. São Paulo: Paz e Terra, 1979.

GUATTARI, F. Caosmose: um novo paradigma estético. Rio de Janeiro: editora 34, 1993.

JAMESON, F. Pós-modernismo: a lógica cultural do capitalismo tardio. São Paulo: Ática, 1996.

LYOTARD, J-F. Heidegger e os judeus. Petrópolis: Vozes, 1994.

MARTÍN-BARBERO, J. Dos meios às mediações. Rio de Janeiro: UFRJ, 2003.

Oficio de cartógrafo: travesías latino-americanas

de la comunicación en la cultura. México: Fondo de Cultura Económica, 2002.

MONS, A. La metáfora social. Buenos Aires: Nueva Visón, 1994.

MORIN, E. O paradigma perdido. Lisboa: Europa-América, 2000. 
PELBART, P. "O salto de mefisto". Imagens, Campinas, n. 2 (Violência), ago. 1994

REGUILLO, R. Emergencias de culturas juveniles: estratégias del desencanto. Bogotá: Norma, 2000.

ROCHA, R. de M. "Comunicação e consumo: por uma leitura política dos modos de consumir”. In: BACCEGA, Maria Aparecida (Org.). Comunicação e culturas do consumo. São Paulo: Atlas, 2008. . "Imagens limiares: primeiras fundamentações para uma imagética do consumo". Cadernos de Pesquisa ESPM, São Paulo, v. 1, n. 4, 2009.

ROCHA, R. de M. "Políticas de visibilidade como fatos de afecção: que ética para as visualidades?”. Revista Famecos, Porto Alegre, v. 17, n. 3, set.-dez. 2010. Disponível em: <http://revistaseletronicas.pucrs. br/ojs/index.php/revistafamecos/article/viewFile/8187/5876>.

ROCHA, R. de M. e COSTA DA SILVA, J. "Consumo, cenários comunicacionais e subjetividades juvenis”. E-compós, Brasília, v. 9, ago. 2007.

ROCHA, R. de M. e PORTUGAL, D. B.. "Culturas do consumo e culturas juvenis no Brasil: marcos históricos e ênfases conceituais nas décadas de 60 e 70". In: VIII NUPECOM - ENCONTRO DOS NÚCLEOS DE PESQUISAS EM COMUNICAÇÃO, Natal, 2008

SARLO, B. Cenas da vida pós-moderna. Rio de Janeiro: UFRJ, 1997.

SPINOZA, B. Ética/Spinoza. Belo Horizonte: Autêntica, 2008.

STRAW, W. "Communities and scenes in popular music". In: GELDER, K., THORNTON, S. (Ed.). The subcultures reader. New York: Routlegde, 1997.

VIRILIO, P. "Olho por olho ou o crash das imagens". Revista Margem, São Paulo, n. 8, p. 25-33, dez. 1998. 